Article

\title{
Evaluation of the Ecotoxicological Potential of Fly Ash and Recycled Concrete Aggregates Use in Concrete
}

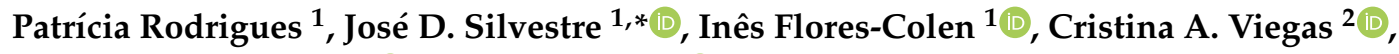 \\ Hawreen $\mathrm{H}$. Ahmed ${ }^{1,3} \mathbb{D}$, Rawaz Kurda ${ }^{1,3}{ }^{-1}$ and Jorge de Brito ${ }^{1}$ \\ 1 CERIS, Instituto Superior Técnico, Universidade de Lisboa, Av. Rovisco Pais, 1049-001 Lisbon, Portugal; \\ patricia.rodrigues@tecnico.ulisboa.pt (P.R.); ines.flores.colen@tecnico.ulisboa.pt (I.F.-C.); \\ hawreen.a@gmail.com (H.H.A.); rawaz.kurda@tecnico.ulisboa.pt (R.K.); jb@civil.ist.utl.pt (J.d.B.) \\ 2 Bioengineering Department and iBB-Institute for Bioengineering and Biosciences, Instituto Superior Técnico, \\ Universidade de Lisboa, Av. Rovisco Pais 1, 1049-001 Lisboa, Portugal; cristina.viegas@tecnico.ulisboa.pt \\ 3 Department of Civil Engineering, Technical Engineering College, Erbil Polytechnic University, Kirkuk Road, \\ Erbil 44001, Kurdistan Region, Iraq \\ * Correspondence: jose.silvestre@tecnico.ulisboa.pt; Tel.: +351-21-841-9709
}

Received: 29 November 2019; Accepted: 30 December 2019; Published: 3 January 2020

\begin{abstract}
This study applies a methodology to evaluate the ecotoxicological potential of raw materials and cement-based construction materials. In this study, natural aggregates and Portland cement were replaced with non-conventional recycled concrete aggregates (RA) and fly ash (FA), respectively, in the production of two concrete products alternative to conventional concrete (used as reference). The experimental program involved assessing both the chemical properties (non-metallic and metallic parameters) and ecotoxicity data (battery of tests with the luminescent bacterium Vibrio fischeri, the freshwater crustacean Daphnia magna, and the yeast Saccharomyces cerevisiae) of eluates obtained from leaching tests of RA, FA, and the three concrete mixes. Even though the results indicated that RA and FA have the ability to release some chemicals into the water and induce its alkalinisation, the respective eluate samples presented no or low levels of potential ecotoxicity. However, eluates from concrete mixes produced with a replacement ratio of Portland cement with $60 \%$ of FA and $100 \%$ of natural aggregates and produced with $60 \%$ of FA and $100 \%$ of RA were classified as clearly ecotoxic mainly towards Daphnia magna mobility. Therefore, raw materials with weak evidences of ecotoxicity could lead to the production of concrete products with high ecotoxicological potential. Overall, the results obtained highlight the importance of integrating data from the chemical and ecotoxicological characterization of materials' eluate samples aiming to assess the possible environmental risk of the construction materials, namely of incorporating non-conventional raw materials in concrete, and contributing to achieve construction sustainability.
\end{abstract}

Keywords: chemical characterization; concrete; construction material; ecotoxicology; fly ash; leachate; raw material; recycled aggregates; sustainability

\section{Introduction}

The interest in using building construction materials with better mechanical, durability, and environmental characteristics is continuously growing [1-6]. However, to obtain such properties, particularly in cement-based materials, some non-conventional raw materials (such as fly ash (FA) and recycled aggregates (RA)), with unknown hazard levels, are being incorporated. Therefore, it is important to determine the ecotoxicological potential of these innovative construction materials and of their raw materials, so that their use and handling are consciously made and contribute to the sustainability of buildings. 
Toxicology is a multidisciplinary science that studies the harmful effects resulting from the interaction between a toxic agent and a biological system in order to predict the advent of these effects. This science encompasses several areas that, depending on the field, have different names, namely ecotoxicology (or environmental toxicology), which studies the toxic effects of xenobiotics on organisms living in ecosystems [7], and occupational toxicology (or human toxicology), which focuses on the study of the harmful effects caused by chemicals present in the workplace [8]. Toxicology can contribute to technological advancement through the implementation of safe conditions of exposure to given substances [9]. To improve construction sustainability, ecotoxicology may have an important contribution in the assessment of the environmental risk associated with the products to be used in the construction sector. For that purpose, it is necessary to evaluate the products' potential ecotoxicity using leaching tests, ecotoxicity tests, and chemical analyses. The assessment of the environmental contamination risk triggered by the contact between surface and groundwater and the materials is done through leaching tests, which allow assessing the mobility of hazardous substances in aqueous media and their environmental impact, although, by themselves, these tests do not reproduce a real situation. These tests should be supplemented with chemical analyses and ecotoxicity testing using biological parameters to understand the influence of the aqueous extracts (e.g., leachates, eluates) on living organisms.

Ecotoxicity tests using the bioluminescent marine bacterium Vibrio fischeri are often used because they are simple, fast, and reproducible. Vibrio fischeri cells emit light when they are healthy, and this luminescence can decrease when the bacterium cells are brought into contact with a toxic agent that causes inhibition of metabolism. This test can be used in the assessment of the potential ecotoxicity of, for instance, leachates or eluates from solid samples like construction materials or ashes [10]. The study by Tsiridis et al. [10] sought to analyse the toxicity of FA and of its elution products to determine the most sensitive bio test in the toxicological assessment and the most effective leaching process. These authors concluded that the Vibrio fischeri test (Microtox test) is suitable for the preliminary screening of solid waste eluate toxicity. However, comparison of data from tests performed with the former bacterium, a freshwater planktonic crustacean Daphnia magna and a freshwater planktonic rotifer Brachionus calyciflorus indicated Daphnia magna as the most sensitive test organism to assess the ecotoxicity of FA eluates [10]. The study also revealed that FA samples obtained from various coal-fired power plants contain heavy metals, namely: $\mathrm{Cr}, \mathrm{Cu}, \mathrm{Mn}, \mathrm{Ni}, \mathrm{Pb}$ and $\mathrm{Zn}$. The results of the eluates' chemical analysis in accordance with EN 12457-2 [11] and with the toxicity characteristic leaching procedure (TCLP) [12] indicated that the chemical compounds present in FA can be transferred to the liquid phase depending on the $\mathrm{pH}$ of the leaching medium. Thus, the $\mathrm{pH}$ of the eluate was also considered an important factor in determining environment contamination and ecotoxicity of FA [10]. In general, the chemical analysis showed the elements $\mathrm{Al}, \mathrm{Ca}, \mathrm{Fe}, \mathrm{Mg}$, and $\mathrm{Cr}$ are the most frequently found in both solid samples and eluates of FA [10].

Choi et al. [13] proved Daphnia magna could be suitable to evaluate the ecotoxicity of leachate from concrete. The leachates of cement samples in acute toxicity test showed $100 \%$ Daphnia magna immobilization upon $24 \mathrm{~h}$ exposure. The authors pointed out the potential negative impact of alkali leaching from concrete into the aquatic environment [13].

The yeast species Saccharomyces cerevisiae is a model eukaryotic microorganism and has been used as a test organism in the assessment of the potential toxicity of pesticides and other environmental contaminants [14]. A study developed by Gil et al. [14] showed that this model is suitable for the development of simple low-cost toxicity tests, which can be useful to provide quick preliminary screening of environmental samples' potential toxicity level, before advancing further to ecotoxicity testing with more complex higher eukaryotes.

Kanare and West [15] studied the composition of leachates obtained from concrete mixes produced with two types of aggregates and four types of Portland cement. The authors used two leachants: acetic acid solution and deionised water. The results with acetic acid showed that $\mathrm{Hg}, \mathrm{Cr}, \mathrm{Pb}$, and $\mathrm{Ni}$ were leached, whereas with the deionised water, only partial leaching of $\mathrm{Hg}, \mathrm{Cr}$, and $\mathrm{Ni}$ occurred. 
Rankers and Hohberg [16] investigated various leaching tests on cementitious mortars with FA. The experiment included four types of tests: glass/polyethylene column test (pH 4 water with nitric acid); DEV-S4 batch test (demineralized water); bottle test ( $\mathrm{pH} 4$ water with nitric acid); and tank-leaching test ( $\mathrm{pH} 4$ water with nitric acid). The first two tests were considered not adequate to construction materials. In the third test, maximum toxic element concentrations were estimated and the results were considered reproducible. The diffusion leaching rates were calculated according to the fourth test, which was also considered reproducible.

Hillier et al. [17] investigated the long-term (up to 256 days) leaching of toxic metals into deionized water from cementitious mortars. The tested samples were analysed according to Directive 80/778/EEC [18] for different metals by using atomic absorption spectroscopy. Of the metals analysed, only vanadium leaching was found in poorly cured mixes [17].

Gwenzi and Mupatsi [19] studied the leachability of heavy metals from cement, sand, and coal ash into water. Total concentrations of $\mathrm{Zn}, \mathrm{Pb}$, and $\mathrm{Mn}$ in coal ash were lower or similar to those in the other materials, whereas total $\mathrm{Fe}$ and $\mathrm{Cu}$ were higher in coal ash. In general, the leached concentrations of $\mathrm{Fe}, \mathrm{Zn}, \mathrm{Cu}, \mathrm{Mn}$, and $\mathrm{Pb}$ from coal ash and from concrete made with it were found low and comparable to that of conventional concrete, suggesting leaching risk. The authors suggested that coal ash can be incorporated in concrete since it is not anticipated to have harmful impact on environmental and public health related to this constituent [19].

In conclusion, the literature review shows that the incorporation of alternatives (FA and RA) to replace conventional components (cement and natural aggregates (NA)) is insufficiently studied in terms of ecotoxicological potential [20]. Moreover, studies concerning concrete mixes with the simultaneous and high incorporation ratio of FA and RA to produce sustainable RA concrete are missing. In this context, this study focuses on the application of an innovative methodology developed in a previous study by the authors [21] that reveals the environmental profile and the potential ecotoxicological risk of raw materials and building materials. In the present study, the developed methodology was applied to three concrete mixes and to raw materials incorporated in them, namely RA and FA. This was intended to assess their environmental risk when considered unusable and sent to landfills. The ecotoxicity results obtained by applying the proposed methodology can be used independently or as part of life cycle assessment (LCA) studies. Generally, these risks are not considered in LCA studies, although being of high relevance to researchers developing innovative and sustainable materials.

\section{Methodology}

A global methodology was proposed in a previous study by the authors [21] for assessing the ecotoxicological potential of materials based on chemical and ecotoxicological tests [22-26]. The proposed global methodology assumes the division of materials into two distinct groups: raw materials (e.g., cement, NA, RA, FA) and construction materials (e.g., concrete). The raw materials group includes materials that are incorporated in cement-based products and is divided into four subgroups: virgin raw materials (VRM); processed raw materials (PRM); recycled and by-product raw materials (RBPRM); and nanomaterials.

A simplified flowchart explaining the methodology adopted to perform the chemical characterization (CC) and ecotoxicological characterization (EC) is presented in Figure 1. Detailed information regarding this methodology can be found in the previous study of the authors [21]. The procedure started with crushing a previously produced source concrete and collecting the remaining RA. Then, the collected RA and other raw materials (FA, cement, NA) were used to produce three new concrete mixes (NAC, C40FA60NA100, C40FA60RA100). The materials' characterization and concrete production are further described in Section 3. The three concrete mixes were then crushed and three types of recycled aggregates (A1, A2, and A3) were produced. After that, the eluates of RA (from the source concrete), FA (raw material), A1, A2, and A3 (from the three concrete mixes) were collected by a leaching procedure and tested for CC and EC (Figure 1) as described in Section 4. 


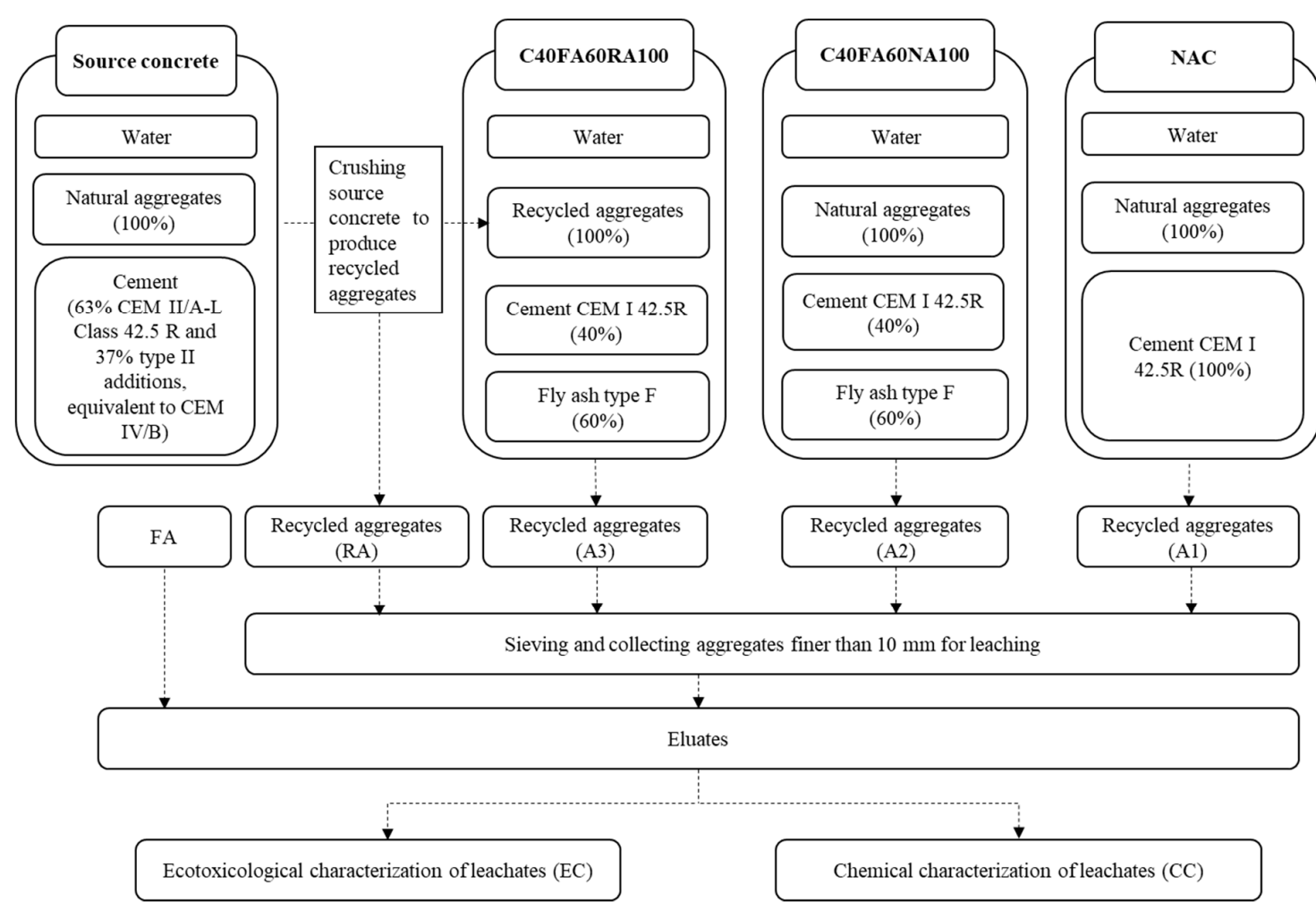

Figure 1. Flowchart of the methodology to perform chemical and ecotoxicological characterizations.

\section{Material Characterization and Concrete Compositions}

The raw materials chosen to produce concrete mixes include: fine natural aggregates (FNA); coarse natural aggregates (CNA); Portland cement (type CEM I $42.5 \mathrm{R}$ ); fine recycled aggregates (FRA); coarse recycled aggregates (CRA); and industrial by-products (FA type F from a Portuguese coal power plant). The materials' characteristics are presented in Tables 1 and 2. FRA and CRA were initially recycled from a source concrete provided by Unibetão Company (Secil, Lisboa, Portugal) with 63\% CEM II/A-L Class $42.5 \mathrm{R}$ and $37 \%$ type II additions, equivalent to CEM IV/B. Prior to crushing, the source concrete was cured and kept outside (exposed to air) for 28 days.

Regarding the construction materials to be studied, three concrete mixes (NAC, C40FA60NA100 and C40FA60RA100) were produced, with the incorporation of the mentioned raw materials (Table 3 and Figure 1). NAC was produced with $100 \%$ NA and 100\% Portland cement, C40FA60NA100 with $40 \%$ cement, $60 \%$ FA and $100 \%$ NA, and C40FA60RA100 with $40 \%$ cement, $60 \%$ FA and $100 \%$ RA in weight. 
Table 1. Characterization of cement and FA.

\begin{tabular}{|c|c|c|c|}
\hline Property & & Cement (CEM 42.5 R) & FA (Type F) \\
\hline $\mathrm{f}_{\mathrm{ctm}}$ at 28 days $(\mathrm{MPa})$ & & 10.1 & - \\
\hline $\mathrm{f}_{\mathrm{cm}}$ at 28 days $(\mathrm{MPa})$ & & 57.7 & - \\
\hline Specific gravity $\left(\mathrm{g} / \mathrm{cm}^{3}\right)$ & & 3.1 & - \\
\hline Residue on $45 \mu \mathrm{m}$ sieve (\%) & & 6.2 & 14.42 \\
\hline Residue on $32 \mu \mathrm{m}$ sieve (\%) & & & 22.48 \\
\hline Final setting $(\mathrm{min})$ & & 231.7 & \\
\hline Initial setting (min) & & 161.1 & \\
\hline \multirow[t]{12}{*}{ Chemical composition (\%) } & $\mathrm{Al}_{2} \mathrm{O}_{3}$ & 5.0 & 20.9 \\
\hline & $\mathrm{CaO}$ & 63.5 & 3.6 \\
\hline & $\mathrm{CaO}(\mathrm{L})$ & 1.3 & \\
\hline & $\mathrm{Cl}^{-}$ & 0.0 & \\
\hline & $\mathrm{Fe}_{2} \mathrm{O}_{3}$ & 3.3 & 7.4 \\
\hline & $\mathrm{K}_{2} \mathrm{O}$ & 0.6 & 1.7 \\
\hline & $\mathrm{MgO}$ & 1.3 & 1.0 \\
\hline & $\mathrm{Na}_{2} \mathrm{O}$ & 0.2 & 1.0 \\
\hline & $\mathrm{SiO}_{2}$ & 19.5 & 57.8 \\
\hline & $\mathrm{SO}_{3}$ & 3.3 & 0.6 \\
\hline & LOI & 2.4 & \\
\hline & IR & 1.2 & 3.8 \\
\hline
\end{tabular}

Table 2. Characterization of natural and recycled aggregates.

\begin{tabular}{cccccccc}
\hline \multirow{2}{*}{ Property } & \multicolumn{2}{c}{ FNA } & \multicolumn{3}{c}{ CNA } & \multirow{2}{*}{ FRA } & CRA \\
\cline { 2 - 6 } & $\begin{array}{c}\text { Coarse } \\
\text { Sand }\end{array}$ & $\begin{array}{c}\text { Fine } \\
\text { Sand }\end{array}$ & $\begin{array}{c}\text { Coarse } \\
\text { Gravel }\end{array}$ & $\begin{array}{c}\text { Fine } \\
\text { Gravel }\end{array}$ & $\begin{array}{c}\text { “Rice } \\
\text { Grain” }\end{array}$ & & \\
\hline Bulk density $\left(\mathrm{kg} / \mathrm{m}^{3}\right)[27]$ & 1684 & 1626 & 1385 & 1391 & 1449 & 1385 & 1280 \\
Oven dried density $\left(\mathrm{kg} / \mathrm{m}^{3}\right)[27]$ & 2600 & 2594 & 2625 & 2742 & 2681 & 2218 & 2389 \\
Water absorption $(\%)[27]$ & 0.5 & 0.4 & 1.4 & 1.2 & 1.0 & 8 & 5 \\
LA abrasion mass loss $(\%)[28]$ & - & - & 28.6 & 27.2 & & - & 43 \\
Shape index [29] & - & - & 15.6 & 18.0 & 17.1 & - & 25.6 \\
\hline
\end{tabular}

Legend: LA = Los Angeles; FNA = Fine natural aggregates; CNA = Coarse natural aggregates; FRA = Fine recycled aggregates; $\mathrm{CRA}=$ Coarse recycled aggregates.

Table 3. Concrete mix design.

\begin{tabular}{ccccccc}
\hline \multirow{2}{*}{ Concrete } & \multicolumn{2}{c}{ Binder (\%) } & \multicolumn{2}{c}{ Natural Aggregates (\%) } & \multicolumn{2}{c}{ Recycled Aggregates (\%) } \\
\cline { 2 - 7 } & Cement & FA & FNA & CNA & FRA & CRA \\
\hline NAC & 100 & 0 & 100 & 100 & 0 & 0 \\
C40FA60NA100 & 40 & 60 & 100 & 100 & 0 & 0 \\
C40FA60RA100 & 40 & 60 & 0 & 0 & 100 & 100 \\
\hline
\end{tabular}

Legend: FA = Fly ash; FNA = Fine natural aggregates; CNA = Coarse natural aggregates; FRA = Fine recycled aggregates; $\mathrm{CRA}=$ Coarse recycled aggregates.

The produced concrete specimens were cured for 28 days in a dry chamber with relative humidity of $50 \pm 5 \%$ and $22 \pm 2{ }^{\circ} \mathrm{C}$ air temperature. Then, the concrete specimens were fragmented through a jaw crusher in conjunction with a vertical shaft impact crusher. After that, the aggregates were sieved with $10 \mathrm{~mm}$ mesh aperture [30]. The three types of aggregates produced from crushing NAC, C40FA60NA100, and C40FA60RA100 were named A1, A2, and A3, respectively. The aggregates recycled from source concrete (named RA) and NAC (named A1) were almost identical, since they were both made with similar NA and cement content. The only differences were in the cement type and curing process of concrete mixes. 


\section{Testing Methods}

The tests performed are summarized in Table 4. The leaching test and further CC and EC of the obtained eluate samples were carried out in the Analytical Laboratory of Instituto Superior Técnico (LAIST, Tecnico-Lisboa, Portugal) following recommended guidelines as indicated (Table 4), except for the yeast growth inhibition test, which used an in-house microplate susceptibility test (Table 4).

Table 4. Testing methods.

\begin{tabular}{cll}
\hline & Tests & \multicolumn{1}{c}{ Methodology } \\
\hline Leaching & Production of eluates & EN 12457-4 [31] \\
& $\mathrm{As}, \mathrm{Hg}, \mathrm{Sb}, \mathrm{Se}$ & ISO 11885 [32] \\
& $\mathrm{Ba}, \mathrm{Cd}, \mathrm{Cr}, \mathrm{Cu}, \mathrm{Mo}, \mathrm{Ni}, \mathrm{Pb}, \mathrm{Zn}$ & SMEWW 4110 [33] \\
& Chloride, Fluoride, Sulphate & SMEWW 2540 [34] \\
Chemical characterization (CC) & Total dissolved solids (TDS) & SMEWW 5310 [35] \\
& Dissolved organic carbon (DOC) & SMEWW 4500 [36,37] \\
& pH & EN 27888 [38] \\
& Electrical conductivity (ELC) & 15 to 30 min exposure in static test (ISO \\
& Inhibition of Vibrio fischeri luminescence & $11348-3$ [39]) \\
& & 24 and 48 h of exposure in static test (ISO \\
& Inhibition of the mobility of Daphnia magna & 6341 [40]) \\
& & 16 h exposure ([14,21]; microplate \\
& Inhibition of yeast growth & susceptibility test)
\end{tabular}

The leaching test was intended to simulate the behaviour of materials when they come into contact with water as leaching agent under given conditions. This test allows predicting the behaviour of the waste if it is deposited in a landfill or in contact with an ecosystem, assuming this process may occur similarly in the environment. In this study, eluate samples were obtained in accordance with the requirements of EN 12457-4 [31]. The test consists of leaching a portion of the solid raw materials with a liquid/solid ratio of 10 over a period of $24 \mathrm{~h}$ at $20 \pm 2{ }^{\circ} \mathrm{C}$. Deionized water (ultrapure) through the Millipore system (Merck KGaA, Darmstadt, Germany) was used as a leaching agent, with practically zero electrical conductivity. The $\mathrm{pH}$ of this water was close to that of rainwater ( $\mathrm{pH} 5-7$ ). The leaching test according to EN 12457-4 [31] required the materials to be fragmented and sieved to obtain particles finer than $10 \mathrm{~mm}$. The mixture of the obtained solid material with the deionized water was placed in a vessel and mechanically agitated for a period of $24 \pm 1 \mathrm{~h}$ in a shaking equipment, with orbital motion. Subsequently, the samples were subjected to vacuum filtration through $0.45 \mu \mathrm{m}$ porosity filter paper and placed in a sterile container at $4{ }^{\circ} \mathrm{C}$ until further analysis (CC and EC).

The CC of the eluate samples aimed at classifying the materials in relation to their potential danger. Therefore, the parameters analysed for CC (Table 4) were selected from the ones established in Directive 1999/31/EC [23] and in EC Decision 2003/33/EC [24] that regulate the acceptance of solid waste in landfills; most of them are also present in the French proposal on Criteria on the Evaluation Methods for Waste Ecotoxicity (CEMWE) [25].

The EC of the eluates allows detecting the effect of chemical components that may be present in solution, translating this information into an effect on a test organism used as a bioindicator. In this study, the EC of the samples was made using a battery of three short-term acute toxicity tests with the following test organisms: Vibrio fischeri, Daphnia magna, and Saccharomyces cerevisiae (Table 4), as described before [21]. Briefly, the degree of toxicity was determined from the measurement of the harmful effects caused by various concentrations of each sample, comprising the undiluted eluate sample (100\% sample) and a dilution series of it (nominal concentrations: $75 \%, 50 \%, 25 \%, 12.5 \%, 6.25 \%$, and $3.125 \%$ ), on the test organisms. For each undiluted or diluted sample, the endpoint measured was bioluminescence upon 30-min exposure for Vibrio fischeri, mobility after 24- and 48-h exposure for Daphnia magna, or growth after 16-h exposure for the yeast (Table 4). The toxicity index $E C_{50}$, namely the median-effective concentration of each eluate sample (an eluate concentration that causes a response decrease in the exposed organism population to $50 \%$ of that measured in a non-toxic control sample), was determined [21]. These toxicity indexes were further processed following the Toxicity 
Classification System (TCS) of Persoone et al. [41] in order to facilitate sorting the samples according to their measured ecotoxicity level. Therefore, the $E C_{50}$ values obtained for each test and eluate sample were converted into toxicity units (TU) as per Equation (1) [41]:

$$
\mathrm{TU}=\left(1 / E C_{50}\right) \times 100
$$

The calculated TU values allowed classifying each eluate sample into one of the five ecotoxicity classes defined by Persoone et al. [41], as seen in Table 5. This classification is based on the highest TU value determined for each sample in the battery of tests performed battery (i.e., based on the most sensitive ecotoxicity test).

Table 5. Ecotoxicity classes defined according to the TCS system [41].

\begin{tabular}{cccccc}
\hline Classes & I & II & III & IV & V \\
\hline Toxicity level & $\begin{array}{c}\text { No acute } \\
\text { toxicity }\end{array}$ & $\begin{array}{c}\text { Low acute } \\
\text { toxicity }\end{array}$ & Acute toxicity & $\begin{array}{c}\text { High acute } \\
\text { toxicity }\end{array}$ & $\begin{array}{c}\text { Very high acute } \\
\text { toxicity }\end{array}$ \\
TU & $\leq 0.4$ & $0.4<\mathrm{TU} \leq 1.0$ & $1.0<\mathrm{TU} \leq 10$ & $10<\mathrm{TU}<100$ & $\mathrm{TU} \geq 100$ \\
\hline
\end{tabular}

\section{Results and Discussion}

The application of the proposed methodology to classify the materials under study in terms of hazard regarding the acceptance of solid waste at landfills and ecotoxicological potential allowed obtaining the results that are presented in Table 6. NA are considered VRM, which were previously classified as inert raw materials with no evidence of ecotoxicity (NOE) (Table 6 and [21]); this result can be supported by the study of Barbudo et al. [42].

Table 6. Classification of the raw materials and of the concrete mixes according to the EC Decision 2003/33/EC (pursuant to Directive 1999/31/CE), the document of the CEMWE French proposal and the TCS system.

\begin{tabular}{|c|c|c|c|c|c|c|}
\hline \multirow{2}{*}{\multicolumn{2}{|c|}{ Materials }} & \multirow{2}{*}{\multicolumn{2}{|c|}{$\begin{array}{c}\text { Chemical Characterization } \\
\text { Directive 1999/31/EC [23] } \\
\text { EC Decision 2003/33/EC [24] }\end{array}$}} & \multicolumn{3}{|c|}{ Ecotoxicological Characterization } \\
\hline & & & & \multicolumn{2}{|c|}{ CEMWE [25] } & \multirow{2}{*}{$\begin{array}{c}\text { TCS (Persoone } \\
\text { et al. [41]) }\end{array}$} \\
\hline & & Class & Parameter & Class & Parameter & \\
\hline \multirow{4}{*}{$\begin{array}{c}\text { Raw } \\
\text { materials }\end{array}$} & NA & Inert & - & NOE & $\mathrm{n} / \mathrm{a}$ & $\mathrm{n} / \mathrm{a}$ \\
\hline & Cement & - & - & NOE & $\mathrm{n} / \mathrm{a}$ & $\mathrm{n} / \mathrm{a}$ \\
\hline & RA & Non-dangerous & TDS & NOE & $\mathrm{n} / \mathrm{a}$ & Class III \\
\hline & FA & Hazardous & $\mathrm{Se}, \mathrm{Cr}, \mathrm{Mo}$ & $\mathrm{NOE}$ & $\mathrm{n} / \mathrm{a}$ & Class III \\
\hline \multirow{3}{*}{$\begin{array}{c}\text { Construction } \\
\text { materials }\end{array}$} & A1 & Non-dangerous & TDS & NOE & $\mathrm{n} / \mathrm{a}$ & Class III \\
\hline & $\mathrm{A} 2$ & Non-dangerous & TDS, Cr, Mo & Ecotoxic & D. magna & Class IV \\
\hline & A3 & Non-dangerous & TDS, Cr, Mo & Ecotoxic & D. magna & Class IV \\
\hline
\end{tabular}

Legend: NA = Natural aggregates; RA = Recycled aggregates; FA = Fly ash; A1 = Aggregates recycled from NAC; A2 = Aggregates recycled from C40FA60NA100; A3 = Aggregates recycled from C40FA60RA100; TDS = Total dissolved solids; NOE = No evidence of ecotoxicity; $\mathrm{n} / \mathrm{a}=$ Not applicable; $D$. magna = Daphnia magna; Class III = Acute Toxicity; Class IV = High Acute Toxicity.

According to the European regulation for Registration, Evaluation, Authorization and Restriction of Chemicals (REACH) [43], Portland cement is considered a well-defined mixture (Table 1); it is in the RBPRM group of raw materials. The existence of a safety data sheet (SDS) for Portland cement shows that this mixture meets the criteria for the classification of hazardous substances set out in the CLP regulation [44]. According to the information provided in the SDS, this material could be classified as non-dangerous for the aquatic environment [44]. Thus, it was not considered necessary to perform the CC and EC of cement, and it may be classified as NOE raw material (Table 6). This result is consistent with reports of Hillier et al. [17] and Gwenzi and Mupatsi [19]. 
RA prepared from source concrete also belong to the group of RBPRM. In this study, the CC and EC of eluate sample obtained from RA were performed (results described in Sections 5.1 and 5.2, respectively). The original RA constituents were the following raw materials: water, NA and cement (CEM II/AL 42.5R), which already have been classified [2]. Therefore, in the particular case in which RA were obtained from the crushing of factory-produced concrete with the desired characteristics (Figure 1), and its composition is fully known (Table 2), it can be assumed that the classification of this raw material can be made from the results obtained for the eluates of the aggregates produced from the reference concrete. The compositions are identical, and both the CEM II/AL 42.5R and the CEM I $42.5 \mathrm{R}$ cements (Figure 1 ) are regulated by the same SDS.

A SDS is not available for the FA used in this study; this type of raw material can be considered as potentially non-hazardous (unknown or variable composition substances) and expected to cause no or low ecotoxicological risk to the aquatic environment [21]. However, a REACH product information sheet is available for "coal ashes (residues)" under the REACH Registration number 01-2119491179-27-0012, which reports measurable no-observed-effect-concentration (NOEC) values for coal ashes towards representative organisms of freshwater, marine and soil ecosystem. Therefore it was found important to examine eluate samples obtained from the FA used in the present study in terms of CC and EC; the results were reported for the first time in [21] and are herein compared with the CC and EC data for the concrete mixes under study (in Sections 5.1 and 5.2, respectively).

The incorporation of RA and FA in cementitious building materials, respectively replacing NA and cement, may have environmental benefits because they avoid landfilling of waste considered hazardous such as FA.

\subsection{Chemical Characterization (CC) of RA, FA, A1, A2 and A3 Eluate Samples}

The results for the non-metallic and metallic parameters from the CC of the eluate samples obtained from of the raw materials (RA and FA) and concrete mixes (A1, A2, and A3) under study are presented in Table 7.

Table 7. Data of the chemical characterization of the eluate samples.

\begin{tabular}{ccccccc}
\hline & & RA & FA & A1 & A2 & A3 \\
\hline \multirow{4}{*}{ Pon-metallic parameters } & & 12.5 & 11.8 & 12.5 & 12.4 & 12.1 \\
& $\mathrm{pH}$ at $2{ }^{\circ} \mathrm{C}$ & 6950 & 1672 & 6950 & 4300 & 3560 \\
& $\mathrm{ELC}(\mathrm{\mu S} / \mathrm{cm})$ & 88 & 23 & 88 & 11 & 100 \\
& $\mathrm{DOC}(\mathrm{mg} / \mathrm{kg})$ & 17,000 & 6450 & 17,000 & 12,000 & 9200 \\
& $\mathrm{TDS}(\mathrm{mg} / \mathrm{kg})$ & 15 & $<30$ & 15 & 19 & 34 \\
& Chloride $(\mathrm{mg} / \mathrm{kg})$ & $<10$ & $<10$ & $<10$ & $<10$ & $<10$ \\
& Fluoride $(\mathrm{mg} / \mathrm{kg})$ & $<30$ & 4400 & $<30$ & $<30$ & 37 \\
& Sulphate $(\mathrm{mg} / \mathrm{kg})$ & $<0.4$ & $<0.4$ & $<0.4$ & $<0.4$ & $<0.4$ \\
& $\mathrm{As}$ & 4.0 & 4.6 & 4.0 & 9.0 & 8.0 \\
& $\mathrm{Ba}$ & $<0.1$ & $<0.1$ & $<0.1$ & $<0.1$ & $<0.1$ \\
& $\mathrm{Cd}$ & $<0.5$ & 2.5 & $<0.5$ & 0.5 & 0.7 \\
Metallic parameters & $\mathrm{Cr}$ & $<1.0$ & $<0.5$ & $<1.0$ & $<1.0$ & $<1.0$ \\
$(\mathrm{mg} / \mathrm{kg})$ & $\mathrm{Cu}$ & $<0.2$ & $<0.2$ & $<0.2$ & $<0.2$ & $<0.2$ \\
& $\mathrm{Hg}$ & $<0.4$ & $<0.4$ & $<0.4$ & $<0.4$ & $<0.4$ \\
& $\mathrm{Mo}$ & $<0.5$ & $<0.5$ & $<0.5$ & $<0.5$ & $<0.5$ \\
& $\mathrm{Ni}$ & $<0.4$ & $<0.4$ & $<0.4$ & $<0.4$ & $<0.4$ \\
& $\mathrm{~Pb}$ & $<0.2$ & 4.0 & $<0.2$ & $<0.2$ & $<0.2$ \\
& $\mathrm{Sb}$ & $<0.5$ & $<0.5$ & $<0.5$ & $<0.5$ & $<0.5$ \\
\hline
\end{tabular}

Legend: ELC = Electrical conductivity; DOC = Dissolved organic carbon; TDS = Total dissolved solids; RA = Recycled aggregates; FA = Fly ash; A1 = Aggregates recycled from NAC; A2 = Aggregates recycled from C40FA60NA100; A3 = Aggregates recycled from C40FA60RA100. 
Regarding the non-metallic parameters, it was found that all the eluate samples were highly alkaline, with $\mathrm{pH}$ values varying in the following order: $\mathrm{FA}(\mathrm{pH}=11.8)<\mathrm{A} 3(\mathrm{pH}=12.1)<\mathrm{A} 2$ $(\mathrm{pH}=12.4)<\mathrm{A} 1=\mathrm{RA}(\mathrm{pH}=12.5)$ (Table 7). The lower $\mathrm{pH}$ value of FA was compared with the results of Moreno et al. [45] and Tsiridis et al. [10]. The value from our study was closer to the mean value of Tsiridis et al. [10], possibly because the leachates were produced based on the same standard procedure [31]. The $\mathrm{pH}$ values of $\mathrm{RA}, \mathrm{A} 1, \mathrm{~A} 2$ and $\mathrm{A} 3$ eluates are common in this type of construction materials; they are close to concrete's pH (approximately 12.5) and are slightly higher than that of FA (Table 7). These high $\mathrm{pH}$ values may be due to the presence of carbonates, oxides and hydroxides formed during combustion processes [26]. On what concerns the concrete mixes, it is worthy to note that the eluate $\mathrm{pH}$ slightly decreased (about $0.4 \mathrm{pH}$ units) with the incorporation of $60 \%$ of FA and $100 \%$ of RA (comparing A3 to A1; Table 7). However, as the $\mathrm{pH}$ value of FA depends on the sulphur content of the source coal, it can vary between 4.5 and 12.0 [46,47]. Therefore, this study suggests that the incorporation of FA in concrete may lead to a decrease of the $\mathrm{pH}$ of the respective eluates, possibly contributing to a lower possible negative impact of alkaline eluate runoff (for instance, due to heavy raining) into aquatic environments, in landfills and/or during building service.

Regarding acceptability as solid waste in landfills, the raw materials (FA and RA) and concrete mixes (A1, A2 and A3) cannot be considered inert because the TDS concentration values measured in the respective eluate samples (Table 7) are higher than the limit value of $4000 \mathrm{mg} / \mathrm{kg}$ defined in the EC Decision 2003/33/EC [24] for inert waste. However, based solely on TDS measurements, they can be considered as non-hazardous waste (Table 6) since the TDS values are lower than the limit values $\left(60 \times 10^{3} \mathrm{mg} / \mathrm{kg}\right)$ defined for non-hazardous waste in the same EC Decision [24].

Regarding the concentration of sulphate $\left(\mathrm{SO}_{4}^{2-}\right)$, a sulphur (VI) compound, FA showed the highest value among all the materials $(4400 \mathrm{mg} / \mathrm{kg}$ ), much higher than the limit values defined in the EC Decision 2003/33/EC [24]. Therefore, in terms of the sulphate concentration, it is advisable to use FA in concrete because the solidification process caused by the hydration of this binder is effective on retaining heavy metals, namely sulphate. The sulphate concentration in the remaining samples was close to $30 \mathrm{mg} / \mathrm{kg}$, much lower than the limit values [24].

On what concerns the metallic parameters analysed in the eluate samples (Table 7), of the studied elements, $\mathrm{Cd}, \mathrm{Hg}, \mathrm{Ni}$, and $\mathrm{Pb}$ belong to the list of priority substances in the field of water policy and $\mathrm{Cd}$ and $\mathrm{Hg}$ are considered priority hazardous substances [48]. From this set of metals evaluated in the RA sample, only Ba presented a concentration value above the limit of quantification $(4.0 \mathrm{mg} / \mathrm{kg})$ (Table 7). RA can be considered a non-hazardous waste because the concentrations of all the elements in the respective eluate (Table 7) were lower than the limit values established for non-hazardous waste the EC Decision 2003/33/EC [24] (Table 6). On the contrary, in the FA eluate sample, Ba (4.6 mg/kg), Cr $(2.5 \mathrm{mg} / \mathrm{kg}), \mathrm{Mo}(10 \mathrm{mg} / \mathrm{kg})$ and Se $(4.0 \mathrm{mg} / \mathrm{kg})$ were detected at concentrations above the quantification limits (Table 7). The concentration values of metals leached from the FA in this study were close to the average values obtained by Moreno et al. [45] (determined based on 23 different samples of FA). In the present work, among these metal concentrations, only Se is above the limit value $(0.5 \mathrm{mg} / \mathrm{kg})$ defined for non-hazardous waste in EC Decision 2003/33/EC [24] and thus FA is classified as potentially hazardous for the environment (Table 6 and [21]).

For the eluate samples from A1, A2, and A3, only Ba, Cr, and Mo showed concentrations above the minimum detection limit (Table 7). A1 eluate presented a Ba concentration $(4.0 \mathrm{mg} / \mathrm{kg})$ lower than that of FA $(4.6 \mathrm{mg} / \mathrm{kg})$; the remaining metal parameters showed concentration values lower than the detection limit (Table 7). For the A2 sample, the Ba concentration $(9.0 \mathrm{mg} / \mathrm{kg}$ ) was approximately twice the one recorded in the FA sample, while the concentrations of $\mathrm{Cr}$ and Mo were $80 \%$ and $94 \%$ lower in A2 compared with FA, respectively (Table 7). A similar trend was observed for the A3 sample (Table 7). It is worthy of note that the concentration of Se for all three concrete samples was zero or below the detection limit (Table 7). Importantly, the results show that all the metals concentrations in the A1, A2 and $\mathrm{A} 3$ eluates were lower than the limit values defined for non-hazardous waste in the landfill EC Decision [24]. 
Overall, based on the results obtained from the CC, the samples RA, A1, A2, and A3 were classified as non-dangerous and the sample FA as potentially hazardous regarding possible contamination of aquatic environments associated to possible leaching of metals from waste disposal in landfills (Table 6).

\subsection{Ecotoxicological Characterization (EC) of $R A, F A, A 1, A 2$ and $A 3$ Eluate Samples}

The results of the EC are presented in Table 8. Despite the alkaline nature and slightly different $\mathrm{pH}$ of the tested eluates samples (Table 7), no corrections were made to their $\mathrm{pH}$ values in toxicity testing, since it was intended to simulate environmental exposure conditions as close as possible to the real ones. Therefore, the ecotoxicity indexes and TU values presented in Table 8 combine the contributions of possible harmful effects associated not only with the chemical components present in the eluate samples but also with their alkaline $\mathrm{pH}$ values.

Table 8. Ecotoxicological characterization results.

\begin{tabular}{|c|c|c|c|c|c|c|c|c|c|}
\hline \multirow{2}{*}{ Materials } & \multirow{2}{*}{$\mathrm{pH}$} & \multicolumn{2}{|c|}{$\begin{array}{c}\text { Bacterium Vibrio } \\
\text { fischeri }\end{array}$} & \multicolumn{4}{|c|}{ Crustacean Daphnia magna } & \multicolumn{2}{|c|}{$\begin{array}{c}\text { Yeast } \\
\text { Saccharomyces } \\
\text { cerevisiae }\end{array}$} \\
\hline & & $\begin{array}{l}E C_{50}(\%) \\
{[30 \mathrm{~min}]}\end{array}$ & TU & $\begin{array}{c}E C_{50}(\%) \\
{[24 \mathrm{~h}]}\end{array}$ & $\begin{array}{c}\text { TU } \\
{[24 \mathrm{~h}]}\end{array}$ & $\begin{array}{c}E C_{50}(\%) \\
{[48 \mathrm{~h}]}\end{array}$ & $\begin{array}{c}\text { TU } \\
{[48 \mathrm{~h}]}\end{array}$ & $\begin{array}{c}E C_{50}(\%) \\
{[16 \mathrm{~h}]}\end{array}$ & TU \\
\hline RA & 12.5 & $>100$ & $<1$ & 18.8 & 5.3 & 14.6 & 6.8 & 19.8 & 5.1 \\
\hline FA & 11.8 & 49.3 & 2.0 & 30.8 & 3.2 & 30.8 & 3.2 & $>100$ & $<1$ \\
\hline A1 & 12.5 & $>100$ & $<1$ & 18.8 & 5.3 & 14.6 & 6.8 & 19.8 & 5.1 \\
\hline $\mathrm{A} 2$ & 12.4 & $>100$ & $<1$ & 6.8 & 15 & 5.5 & 18.8 & 30.2 & 3.3 \\
\hline A3 & 12.1 & $>100$ & $<1$ & 13.6 & 7.4 & 7.7 & 12.9 & 40.7 & 2.5 \\
\hline
\end{tabular}

Legend: RA = Recycled aggregates; FA = Fly ash; A1 = Aggregates recycled from NAC; A2 = Aggregates recycled from C40FA60NA100; A3 = Aggregates recycled from C40FA60RA100; TU = Toxicity Units; $E C_{50}=$ median-effective concentration for the endpoint in each test.

The eluate sample of RA (equal to A1) did not cause inhibition of Vibrio fischeri luminescence. Comparatively, the toxicity of the same samples to Daphnia magna and Saccharomyces cerevisiae test organisms was higher (Table 8). These results suggest that the bioluminescent bacterium was not sensitive to exposure to the RA (or A1) sample. On the contrary, the crustacean and the yeast tests presented similar results between them, with TU values between 5.3 and 6.8 in the Daphnia magna toxicity test ( $24 \mathrm{~h}$ and $48 \mathrm{~h}$ exposure, respectively) and equal to 5.1 in the yeast toxicity test (16 h exposure) (Table 8). These TU values higher than 1 but considerably lower than 10 (TCS system [41]; Table 5) in both toxicity tests with RA (or A1) indicate potentially low acute ecotoxicity (class III) of these materials (Table 6).

Regarding the FA eluate sample, Vibrio fischeri bioluminescence and Daphnia magna mobility were both moderately affected by this sample, contrary to the yeast growth which was not inhibited upon exposure to the FA sample (Table 8 and [21]). The results reported in the study of Tsiridis et al. [10,49] indicated Daphnia magna among the diverse test organisms they used (bacteria, microalga, crustacean, and rotifer), to be the most sensitive test organism in the evaluation of the ecotoxicity of coal FA leachates $[10,49]$. The authors attributed this result to the lower tolerance of this invertebrate to the presence of high $\mathrm{Cr}$ concentration in the samples [49]. This study also revealed that the presence of $\mathrm{Cu}, \mathrm{Ni}$, and $\mathrm{Zn}$ in the leachate samples resulted in a significant bioluminescence inhibition of Vibrio fischeri. In our study, the concentrations of these metals in all eluate samples are very low (Table 7), so the resulting effect is expected to be low. The TU values much lower than 10 (TCS system [41]; Table 5) in both Daphnia magna and Vibrio fischeri toxicity tests (TU = 3.2 and 2, respectively; Table 8), suggest very low acute ecotoxicity (class III) of FA eluate (Table 6).

The eluate samples of A2 and A3 did not cause inhibition of Vibrio fischeri bioluminescence. However, both the crustacean mobility and the yeast growth were considerably affected by the A2 and the A3 samples (Table 8). In both cases, the comparison of the respective TU values indicated that 
the Daphnia magna toxicity test (TU [24 h] = 7.4 and 15 for A3 and A2, respectively) was much more sensitive than the yeast one (TU $[16 \mathrm{~h}]=2.5$ and 3.3, respectively) (Table 8). Based on the TU values $>10$ for the most sensitive ecotoxicity test used, i.e., $48 \mathrm{~h}$ mobility for Daphnia magna (Table 8), the samples A2 and A3 were classified as moderate-highly toxic (class IV) (Table 6). Comparatively, both the A3 and A2 samples were found to exert higher levels of ecotoxicity towards the freshwater model crustacean than the A1 sample, and the order of potential ecotoxicity is: A2 > A3 > A1 (Tables 6 and 8).

Given the results obtained, there was also no evidence to classify the eluate samples of RA, FA and A1 as ecotoxic (Table 6), since the results of CC and EC for these materials (Tables 7 and 8) comply with the limit values established in the French proposal CEMWE [25]. However, the results obtained for samples A2 and A3 allow classifying these materials as potentially ecotoxic based on the fact that the limit value of $10 \%$ for $48 \mathrm{~h}$ mobility $E C_{50}$ in Daphnia magna (corresponding to $\mathrm{TU}=10$ in Table 5) defined in the French proposal CEMWE [25] was exceeded (Table 6).

There are reports by other authors of a considerable sensitivity of Daphnia magna invertebrates when suspended in alkaline media ( $\mathrm{pH}$ values as high as 11.3) [26]. In our work, despite the high $\mathrm{pH}$ values of all the eluate samples tested (Table 8), $\mathrm{pH}$ is not anticipated to be the only relevant factor contributing to the negative effects of the samples of this model invertebrate. This is because eluates from RA (A1) with a pH value of 12.5 were found much less toxic to the crustacean than the $\mathrm{A} 2$ and A3 eluates with $\mathrm{pH}$ values equal to 12.4 and 12.1, respectively (Table 8). Therefore, other factors, for instance the release of chemical compounds, including metals, from these materials into water due to leaching, may be influencing the biological response of the test-organism to the eluates' samples, as reported by others $[13,19]$.

Of the three short-term ecotoxicity tests used (with Vibrio fischeri, Daphnia magna, and Saccharomyces cerevisiae), the most sensitive one in analysing the ecotoxicity of cement-based raw and construction materials was the standard acute mobility test with the freshwater crustacean Daphnia magna. On the contrary, the bioluminescent bacterium test was the least sensitive to all eluates' samples, while the microplate susceptibility test with Saccharomyces cerevisiae showed an intermediate response (except for the FA eluate sample). In this study, the yeast-based test is proposed as a suitable test for preliminary screening of the potential ecotoxicity of raw and construction materials. Even though a relatively low sensitivity of the yeast test, compared with the Daphnia magna one, should be recognized, the yeast test provides some relevant advantages as test system, namely: sparing of higher eukaryotes in toxicity testing (required by regulators, e.g., REACH); meaningfulness of data for eukaryotic microorganisms that provide relevant services in ecosystems; simplicity; low-cost; small-scale (96-well microplate format) and reproducibility [21].

The potential leaching of metals and other chemicals from FA, A2 and A3 was very low for almost all analysed metals, including the ones in the European Union list of priority substances in the field of water policy (e.g., $\mathrm{Cd}, \mathrm{Hg}, \mathrm{Pb}$, and $\mathrm{Ni}$ ) [44]. Nevertheless, regarding landfill deposition and based on the CC alone, FA eluate was classified as hazardous (due to the Se level) while the eluates of A2 and $\mathrm{A} 3$ were considered non-hazardous (due to Mo and TDS levels) (Table 6). On the contrary, based on EC, the former was NOE or class III (according to CEMWE or TCS, respectively) while the latter were classified as class IV based on ecotoxicity towards Daphnia magna (Table 6). These changes can be due to possible differences in the chemical composition of the eluates and/or in other parameters not analysed in this work. Based on the data presented in this work and on other studies $[19,26]$, it can also be suggested that the alkaline $\mathrm{pH}$ of eluates from FA ( $\mathrm{pH} 11.8)$ and concrete $(\mathrm{pH} 12.5$ and 12.4 for $\mathrm{A} 1$ and A2, respectively) may be relevant in this respect and may contribute to possible environmental risks. Such risks can be especially important if leachates or eluates from concrete or FA are produced in buildings in service (e.g., due to rain events) and/or in landfills and can reach freshwater ecosystems leading to water alkalinisation. Therefore, results obtained in this study highlight the importance of integrating data from CC and EC of materials' eluate samples aiming at assessing the possible environmental risk of the construction materials, as suggested by other authors [26,50]. 
The incorporation of raw materials that have a low ecotoxicity level (e.g., FA, RA) in construction materials can however generate construction materials leading to eluates with a significantly higher toxicity level. For example, A1, coming from a concrete with $100 \%$ NA and $100 \%$ cement, has a toxicity level lower than that of A2 and A3 where natural aggregates and Portland cement were partially replaced with non-conventional RA and FA. In fact, it seems relevant that although FA has a low ecotoxicological potential (Table 6), when this raw material was incorporated in concrete mixes in a given quantity ( $60 \%$ in the present study) it did not contribute to diminish the potential ecotoxicity of the respective eluates.

The literature states that the cement-based construction materials that raise the most concerns in terms of ecotoxicological risk are those that incorporate RA. However, the incorporation of by-products (FA) in such materials may also contribute to some non-negligible environmental risk. These raw materials have a variable chemical composition that is often unknown.

\section{Conclusions}

From the application of a methodology proposed in a previous study [21] to three concrete mixes (A1, A2, A3), in order to compare the ecotoxicological potential of raw materials (fly ash-FA, recycled aggregates-RA) and cement-based construction materials, the following conclusions were drawn:

- Taking into account only the chemical characterization (CC) of the eluates and the comparison of the results obtained with limit values established in the landfill waste EC Decision 2003/33/EC [24], the concrete mixes formulated with raw materials classified as hazardous (FA) may be classified as non-hazardous materials (A2 and A3).

- Materials with a high ecotoxicological potential, namely samples A2 and A3, can be formulated from raw materials with evidence of lower ecotoxicity (FA and RA). This result is corroborated by TCS, which showed that the ecotoxicity degree of construction materials formulated with ecotoxic raw materials was greater than that of their raw materials; an increase in toxicity occurs from the raw materials (Class III) to the construction materials (Class IV). Thus, the incorporation of $100 \%$ RA and $60 \%$ FA in concrete may result in an adverse effect on human health and on the environment.

- The incorporation of high quantities of FA with an extremely high sulphate concentration ( $4400 \mathrm{mg} / \mathrm{kg}$ ) in concrete reduced the concentration to $30 \mathrm{mg} / \mathrm{kg}$ for the samples A1, A2, and A3. The concentration of chlorides was low in FA, but increased slightly when incorporated in concrete.

In this study, the importance of assessing the possible environmental risks of the incorporation of non-conventional raw materials in cement-based construction materials was demonstrated. The chemical and ecotoxicological characterization of materials' eluate samples can complement environmental life cycle assessment studies and contribute to achieving construction sustainability.

Author Contributions: P.R. developed and applied the methodology to concrete mixes. J.D.S. and I.F.-C. supervised the research work based on a master thesis and reviewed the paper. C.A.V. carried out ecotoxicity tests, helped in the interpretation of the results and reviewed the paper. H.H.A. wrote the paper. R.K. formulated and produced the concrete mixes. J.d.B. reviewed and edited the paper. All authors have read and agreed to the published version of the manuscript.

Funding: This research was funded by FCT_Foundation for Science and Technology, Portugal, via the Project FCT PTDC/ECM/118372/2010—EXCELlentSUStainableCONcrete.

Acknowledgments: The authors wish to thank CERIS research centre and iBB-Institute for Bioengineering and Biosciences from IST, FCT-Foundation for Science and Technology (UID/BIO/04565/2013 for iBB), Programa Operacional Regional de Lisboa 2010 (Lisboa-01-0145-FEDER-007317 for iBB) and to WGB Shield research project (FCT-PTDC/ECI-EGC/30681/2017).

Conflicts of Interest: The authors declare no conflict of interests. 


\section{References}

1. Sunayana, S.; Barai, S.V. Performance of fly ash incorporated recycled aggregates concrete column under axial compression: Experimental and numerical study. Eng. Struct. 2019, 196, 109258. [CrossRef]

2. Kurad, R.; Silvestre, J.D.; de Brito, J.; Hawreen, A. Effect of incorporation of high volume of recycled concrete aggregates and fly ash on the strength and global warming potential of concrete. J. Clean. Prod. 2017, 166, 485-502. [CrossRef]

3. Kurda, R.; de Brito, J.; Silvestre, J.D. Water absorption and electrical resistivity of concrete with recycled concrete aggregates and fly ash. Cem. Concr. Compos. 2019, 95, 169-182. [CrossRef]

4. Arezoumandi, M.; Drury, J.; Volz, J. Effect of recycled concrete aggregate replacement level on the fracture behavior of concrete. ACI Mater. J. 2015, 3, 1-8.

5. Kurda, R.; de Brito, J.; Silvestre, J.D. Carbonation of concrete made with high amount of fly ash and recycled concrete aggregates for utilization of $\mathrm{CO}_{2}$. J. $\mathrm{CO}_{2}$ Util. 2019, 29, 12-19. [CrossRef]

6. Mocová, K.A.; Sackey, L.N.A.; Renkerová, P. Environmental impact of concrete and concrete-based construction waste leachates. IOP Conf. Ser. Earth Environ. Sci. 2019, 290, 012023. [CrossRef]

7. APA. (Portuguese Environment Agency). 2015. Available online: http://apambiente.pt/_zdata/LRA/ Ecotoxicologia.pdf (accessed on 2 April 2015). (In Portuguese).

8. Santos, A. Occupational Toxicology—Toxicity of Organic Solvents; Portuguese Chemical Society: Lisboa, Portugal, 2014; Available online: https://www.spq.pt/magazines/BSPQuimica/567/article/3000492/pdf (accessed on 2 April 2015). (In Portuguese)

9. Nassis, C. Toxicology Fundamentals. 2015. Available online: http://pt.scribd.com/doc/128059485/Fundamentosde-Toxicologia (accessed on 2 April 2015). (In Portuguese).

10. Tsiridis, V.; Samaras, P.; Kunglos, A.; Sakellaropoulos, G. Application of leaching tests for toxicity evaluation of coal fly ash. Environ. Toxicol. 2006, 21, 409-416. [CrossRef]

11. Characterisation of Waste. Leaching. Compliance Test for Leaching of Granular Waste Materials and Sludges. Part 2: One Stage Batch Test at a Liquid to Solid Ratio of $10 \mathrm{~L} / \mathrm{kg}$ for Materials with Particle Size below $4 \mathrm{~mm}$ (without or with Size Reduction); EN 12457-2:2002; Comité Européen de Normalisation: Brussels, Belgium, 2002.

12. Toxicity Characteristic Leaching Procedure; TCLP 1311:1992; United States Environmental Protection Agency (USEPA): Washington, DC, USA, 1992.

13. Choi, J.; Bae, S.; Shin, T.; Ahn, K.; Woo, S. Evaluation of daphnia magna for the ecotoxicity assessment of alkali leachate from concrete. Int. J. Indust. Entomol. 2013, 26, 41-46. [CrossRef]

14. Gil, F.; Santos, M.; Chelinho, S.; Pereira, C.; Feliciano, J.; Sousa, L.J.; Ribeiro, R.; Viegas, C. Suitability of a Saccharomyces cerevisiae-based assay to assess the toxicity of pyrimethanil sprayed soils via surface runoff: Comparison with standard aquatic and soil toxicity assays. Sci. Total Environ. 2015, 505, 161-171. [CrossRef]

15. Kanare, H.M.; West, B.W. Leachability of selected chemical elements from concrete. In Emerging Technologies Symposium on Cement and Concrete in the Global Environment; Portland Cement Association: Chicago, IL, USA, 1993.

16. Rankers, R.H.; Hohberg, I. Leaching tests for concrete containing fly ash-Evaluation and mechanism. Stud. Environ. Sci. 1991, 48, 275-282.

17. Hillier, S.; Sangha, C.; Plunkett, B.; Walden, P. Long-term leaching of toxic trace metals from Portland cement concrete. Cement Concrete Res. 1991, 29, 515-521. [CrossRef]

18. Council Directive 80/778/EEC of 15 July 1980 Relating to the Quality of Water Intended for Human Consumption-Repealed by Council Directive 98/83/EC on the Quality of Water Intended for Human Consumption; Council of the European Union: Brussels, Belgium, 1980.

19. Gwenzi, W.; Mupatsi, N. Evaluation of heavy metal leaching from coal ash-versus conventional concrete monoliths and debris. J. Waste Manag. 2006, 49, 114-123. [CrossRef] [PubMed]

20. Kurda, R.; Silvestre, J.D.; de Brito, J. Toxicity and environmental and economic performance of fly ash and recycled concrete aggregates use in concrete: A review. Heliyon 2018, 4, e00611. [CrossRef] [PubMed]

21. Rodrigues, P.; Silvestre, J.D.; Flores-Colen, I.; Viegas, C.A.; de Brito, J.; Kurad, R.; Demertzi, M. Methodology for the assessment of the ecotoxicological potential of construction materials. Materials 2017, 10, 649. [CrossRef] 
22. Directive 2008/98/EC of the European Parliament and of the Council of 19 November 2008 on Waste and Repealing Certain Directives (Text with EEA Relevance); European Parliament and Council of the European Union: Brussels, Belgium, 2008.

23. Directive 1999/31/EC of 26 April 1999 on the landfill of waste. Off. J. Eur. Communities 1999, L182, 1-19.

24. Council decision 2003/33/EC of the European Community of 19 December 2002 Establishing Criteria and Procedures for the Acceptance of Waste and Landfills Pursuant to Article 16 of and Annex II to Directive 1999/31/EC. Off. J. Eur. Communities 2003, L11, 27-49.

25. Criteria on the Evaluation Methods of Waste Ecotoxicity: Proposal-CEMWE; ADEME 1998; ADEME: Paris, France, 1998.

26. Lapa, N.; Barbosa, R.; Lopes, M.; Mendes, B.; Abelha, P.; Gulyurtlu, I.; Oliveira, J. Chemical and ecotoxicological characterization of ashes obtained from sewage sludge combustion in a fluidised-bed reactor. J. Hazard Mater. 2007, 147, 175-183. [CrossRef]

27. Tests of the Mechanical and Physical Properties of the Aggregates. Part 6: Determination of Density and Water Absorption; EN 1097-6:2013; Comité Européen de Normalisation: Brussels, Belgium, 2013.

28. Tests for mechanical and physical properties of aggregates. In Methods for the Determination of Resistance to Fragmentation; EN 1097-2:1998; Comité Européen de Normalisation: Brussels, Belgium, 1998.

29. Tests to Determine the Geometric Characteristics of the Aggregates. Part 4: Determination of the Shape of the Particles; EN 933-4:2002; Form index; Comité Européen de Normalisation: Brussels, Belgium, 2002.

30. Aggregates for Concrete; IPQ:2002; EN 12620:2002+A1:2010; Instituto Português da Qualidade: Lisboa, Portugal, 2002.

31. Characterization of Waste. Leaching - Compliance Test for Leaching of Granular Waste Materials and Sludges. Part 4: One Stage Batch Test at a Liquid to Solid Ratio of $10 \mathrm{~L} / \mathrm{kg}$ for Materials with Particle Size below $10 \mathrm{~mm}$ (without or with Size Reduction); EN 12457-4:2002; Comité Européen de Normalisation: Brussels, Belgium, 2002.

32. Water Quality_Determination of Selected Elements by Inductively Coupled Plasma Optical Emission Spectrometry (ICP-OES); ISO 11885:2007; International Organization for Standardization: Geneva, Switzerland, 2007.

33. Determination of Anions by Ion Chromatograph. In Standard Methods for the Examination of Water and Wastewater; SMEWW 4110:2017; American Public Health Association, American Water Works Association and Water Environment Federation: Washington, DC, USA, 2017.

34. Solids. In Standard Methods for the Examination of Water and Wastewater; SMEWW 2540:2017; American Public Health Association, American Water Works Association and Water Environment Federation: Washington, DC, USA, 2017.

35. Total Organic Carbon (TOC). In Standard Methods for the Examination of Water and Wastewater; SMEWW 5310:2017; American Public Health Association, American Water Works Association and Water Environment Federation: Washington, DC, USA, 2017.

36. $\mathrm{H}+\mathrm{pH}$ value. In Standard Methods for the Examination of Water and Wastewater; SMEWW 4500:2017; American Public Health Association, American Water Works Association and Water Environment Federation: Washington, DC, USA, 2017.

37. Boron. In Standard Methods for the Examination of Water and Wastewater; SMEWW 4500:2017; American Public Health Association, American Water Works Association and Water Environment Federation: Washington, DC, USA, 2017.

38. Determination of Conductivity — Condutimetry; IPQ:1996. EN 27888:1996; Instituto Português da Qualidade: Lisboa, Portugal, 1996. (In Portuguese)

39. Water Quality-Determination of the Inhibitory Effect of Water Samples on the Light Emission of Vibrio Fischeri (Luminescent Bacteria Test). Part 3: Method Using Freeze Dried Bacteria; ISO 11348-3:2007; International Organization for Standardization: Geneva, Switzerland, 2007.

40. Determination of the Inhibition of the Mobility of Daphnia Magna Straus (Cladocera, Crustacea)—Acute Toxicity Test; ISO 6341:2012; International Organization for Standardization: Geneva, Switzerland, 2012.

41. Persoone, G.; Marsalek, B.; Blinova, I.; Torokne, A.; Zarina, D.; Manusadzianas, L.; Nalecz-Jawecki, G.; Tofan, L.; Stepanova, N.; Tothova, L.; et al. A practical and user-friendly toxicity classification system with microbiotests for natural waters and wastewaters. Environ. Toxicol. 2003, 18, 395-402. [CrossRef]

42. Barbudo, A.; Galvín, A.; Agrela, F.; Ayuso, J.; Jiménez, J. Correlation analysis between sulphate content and leaching of sulphates in recycled aggregates from construction and demolition wastes. J. Waste Manag. 2012, 32, 1229-1235. [CrossRef] 
43. Regulation (EC) 1907/2006 of 18 December 2006, of the European Parliament concerning the Registration, evaluation, authorization and restriction of chemicals (REACH). Off. J. Eur. Union 2006, L396, 1-849.

44. Regulation (EC) 1272/2008 of the European Parliament and of the Council of 16 December 2008 on Classification, Labelling and Packaging of Substances and Mixtures; Europa EU: Brussels, Belgium, 2008.

45. Moreno, N.; Querol, X.; Andrés, J.; Stanton, K.; Towler, M.; Nugteren, H.; Janssen-Jurkovicova, M.; Jones, R. Physico-chemical characteristics of European pulverized coal combustion fly ashes. Fuel 2005, 84, 1351-1363. [CrossRef]

46. Plank, C.; Martens, D. Boron availability as influenced by application of fly ash to soil. Soil Sci. Soc. Am. J. 1974, 38, 974-977. [CrossRef]

47. Page, A.; Elseewi, A.; Straughan, I. Physical and chemical properties of fly ash from coal-fired power plants with special reference to environmental impacts. Residue Rev. 1979, 71, 83-120.

48. Directive 2008/105/EC of the European Parliament and of the Council of 16 December 2008 on Environmental Quality Standards in the Field of Water Policy; Europa EU: Brussels, Belgium, 2008.

49. Tsiridis, V.; Petala, M.; Samara, P.; Kungolos, A.; Sakellaropoulos, G. Environmental hazard assessment of coal fly ashes using leaching and ecotoxicity tests. Ecotoxicol. Environ. Saf. 2012, 84, 212-220. [CrossRef]

50. Directive 2000/60/EC of the European Parliament and of the Council Establishing a Framework for the Community Action in the Field of Water Policy; Europa EU: Brussels, Belgium, 2008.

(C) 2020 by the authors. Licensee MDPI, Basel, Switzerland. This article is an open access article distributed under the terms and conditions of the Creative Commons Attribution (CC BY) license (http://creativecommons.org/licenses/by/4.0/). 